\title{
VISUAL DIGNITY IN ART
}

\author{
RUTH DOROT \\ School of Architecture Ariel University, Ramat Hagolan st., Ariel, Israel \\ E-mail address: sf_moshed@bezeqint.net \\ ORCID: https:/ / orcid.org/0000-0002-1884-1743 \\ Editing: Nili Laufert; Translation: Micaela Ziv
}

\begin{abstract}
Aim. The aim of this article is to deal with visual dignity in the field of western art throughout the ages as it seeks to present the artistic and design devices employed by artists in order to compose and convey this aura of dignity. Moreover, it addresses the ways in which they create various kinds of atmosphere of respect and dignity felt by the observer regarding the topic and object of the painting or sculpture.

Methods. In order to achieve this aim, the article examines seven masterpieces which explore the visual representations of various perceptions of dignity and their implications. Among the elements affecting the creation of dignity in the visual domain one finds: an impressive or majestic appearance, noblesse, self-esteem, pride, self-confidence, inner strength, authoritativeness and charisma. At times, the respectful treatment of the figures is clear as soon as one views the work, but at others it is implied in the interpretation given to it.

It is not this article's intention to discuss the different perceptions or expressions of human dignity, historically, theologically, politically, psychologically, nationally or socially, but to present them artistically as they are the innate right of people to be appreciated, treated with courtesy and met with ethical behavior.

Results and conclusion. The research done in order to reach a conclusion confirming or contradicting the premises at its base, resulted in a mosaic of situations in which human dignity is reflected. The range of possibilities at the artists' disposal for creating this value is diverse and includes: composition, use of color, mimesis, embellishment, disfigurement or distortion of reality.

The pieces examined present: a military commander at the moment of his foe's surrender; an author monumentally impressive, man of vision and power and of grand dimensions, rising up from a stone plinth; a stern-faced, disfigured dwarf considered a 'curiosity', seated on the ground; a family of farmers living an impoverished and meager life; and a Jesus-like mysterious intellectual and Moses the prophet. All these together at first glance appear to be a strange collection of works, in which the common denominator is unclear or seemingly absent. However, this diverse group is included in the article because of the aura of dignity the figures command or convey. At times, the respectful treatment of the figures is clear as soon as one views the work, but at others it is implied in the interpretation given to it.
\end{abstract}

Key words: dignity, humiliation, innate rights, recognition, status, respect, self-esteem, inner-strength, confidence, pride, self-confidence, charisma, impression, achievements, aura.

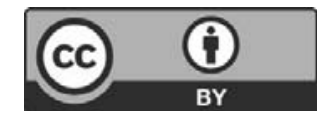




\section{INTRODUCTION}

A ccording to the German philosopher Immanuel Kant (1724-1804), morality went on to say that free will is essential since human dignity is linked to human ability to choose their positive or negative actions (O'Hara, 1999). Others, such as the Swedish philosopher and educator Lennart Nordenfelt define the concept of dignity as follows (Nordenfelt, 2009):

1. a person's value geared towards moral stature, which cannot be undermined or taken away.

2. the dignity a person is worthy of according to their achievements, evaluated according to criteria that afford him social status;

3. dignity according to moral repute dependent on a person's behavior and his or her level of self-respect;

4. dignity of identity given the person's self-respect as a person of integrity, autonomy, and that of a person holding normal relationships with others in their own community. This kind of dignity is vulnerable to attack of others, to illness, and to disability due to accidents or aging.

The meaning and definition of dignity, abstract and concrete alike, are the innate right people have to be appreciated, to be treated with courtesy and ethical behavior. Among the elements affecting the creation of dignity in the visual domain we find: an impressive or majestic appearance, noblesse, self-esteem, pride, self-confidence, inner strength, authoritativeness, charisma and more.

It is not this article's intention to discuss the different perceptions or expressions of human dignity, historically, theologically, politically, psychologically, nationally or socially, but rather to explore the visual representations of various perceptions of dignity and their implications according to six examples of western art. Moreover, it addresses the ways in which artists create various kinds of atmosphere of respect and dignity felt by the observer regarding the topic and object of the painting or sculpture.

This artistic selection builds a mosaic of situations in which human dignity is reflected. The range of possibilities at the artists' disposal for creating this value is diverse and includes composition, use of color, mimesis, embellishment, disfigurement or distortion of reality.

Self-portrait 1500 by Albrecht Dürer (1471-1528) attracts the observer's attention with its aura of mystery. Thomas Hoving, former director of the New York Metropolitan Museum, called it "the single most arrogant, annoying, and gorgeous portrait ever created" (Dobrzynski, 2008).

In 1484, Dürer wrote in the top right-hand corner of his first self-portrait at the age of 13 , "I painted this according to my figure reflected in the mirror" - a description indicating his awareness of the subject and the first documentation showing his character and self-confidence. Dürer, who was greatly preoccupied with the theme of the self-portrait, was one of the great artists of the German Renaissance and was also a writer, philosopher and researcher 
who dealt extensively with the connection between art and science. He painted some 15 self-portraits and is considered to be the one who established this genre in art, which, since the Renaissance, became an independent theme.

In this self-portrait, at the age of 28 , as a figure both sensual and spiritual, Dürer reaches a turning point in terms of maturity - a zenith in self-portrayal. He radiates great confidence and self-awareness, a fully-developed personality that signals completion of the process of self-discovery, which, as mentioned, had already begun all those years earlier.

To the right, at eye-level, he placed a text to immortalize himself: "I, Albrecht Dürer, have painted myself with everlasting colors at the age of 28." His intention was to draw attention to his eyes - an important tool for the artist. In contrast with his earlier portraits, he minimized the "costume" and theatricality obtained from external accessories. Against a very dark background, his figure glows devoid of any reference to place or time filling the painting and directly facing the observer, a style that only began to emerge in the Renaissance of the $16^{\text {th }}$ century. A frontal portrait was considered powerful because of its directness, and especially because until then it had only been intended for portraying Jesus. In this painting he is attired in a nobleman's clothes, displaying a velvet coat in warm hues of brown with its fur trimmings also suggesting his high social rank since his aim was to draw the distinction between himself the artist and his relatives the craftsmen, the goldsmiths. Underpinning this self-portrait is the connotation of Jesus, as mentioned, but on this occasion it is achieved through his long curly locks of hair, flowing, streaming over his shoulders and framing his face. His serious countenance, his eyes looking directly and penetratingly at the observer, his radiant face and the position of his fingers are all reminiscent of Jesus extending a blessing. On the left, the artist's initials - AD, are clearly visible and serve as a stamp and a signature and as a further hint of Jesus as in the abbreviation of Anno Domini (in the year of our Lord). His gravitas, concentration and emotional restraint evoke a complex sense of tremendous dignity towards the figure, as they conjure up associations with images of Jesus the judge. As biographer Marcel Brion put it, "the face has the inflexibility and impersonal dignity of a mask, hiding the restless turmoil of anguish and passions within" (Brion, 1960, p. 170). Dürer's choice of a Jesus-like figure does not stem from being "arrogant, egotistical or blasphemous [since] he was a devout Christian" (Brinkley, 2012 , p. 1), but rather because that was the expression of his belief that his art was a divine gift raising him to a level of genius (Brinkley, 2012).

Tn his painting of Don Sebastián de Morra (1644), Spanish painter, Diego VelaIzquez (1599-1660) relates to the issue of human dignity not as a primary factor but as the result of the fight against humiliation (Edgar, 2003).

In $17^{\text {th }}$ century Spain, the court of King Philip IV was home to a group of dwarves and midgets, some of whom were mentally deficient and served as entertainers and a source of amusement. One of them was Don Sebastián de Morra. This custom completely contradicted the determination of Immanuel 
Kant that human beings should not be used for enjoyment, entertainment or as a target of humiliation (Kant, 1964). Still, their purpose was perceived to be the lifting of the melancholic spirit prevailing at the court due to a hereditary disease that affected the men and spread death and mourning throughout the palace. The court functioned according to extremely rigid social rules regarding dwarves. In their book, Brown and Garrido (1998) claimed that the dwarves were accorded no human dignity as they were outside the 'natural' or 'normal' expectations because of their deformity - an aberration of Creation - that denied them the respect that is attached to 'beautiful' nature (Brown \& Garrido, 1998).

As the court painter, Velazquez included this group of dwarves in his works depicting the gloom climate of the period. As mentioned, one of them was de Morra, shown here against a neutral background, leaning against a wall, sitting on the floor, "not even on a chair" (Jones, 2002, p. 6), while his clothes are elegant and very bright in color. There is an obvious contrast between the expression on his face, his size and sitting position. The artist places him at the eye-level of the observer, who does not look at him top-down. On the contrary: the observer is 'brought down' to the height of the dwarf and their eyes meet. They communicate as equals and this affords the dwarf rights as an equal participant in the social interaction. These rights which are the prerogative of aristocratic subjects are afforded him too, as he dominates the painting in spite of how he is seated, emphasizing the shortness of his limbs. His hands are fisted to hide his stubby short fingers conveying inflexible clumsiness while the position of his legs reveals the distortion of his tiny proportions as do the illuminated soles of his shoes. His feet and shoes point upward in a kind of sharp defiance.

According to the philosopher Axel Honneth (1945), this painting portrays a certain model of dignity relating to this physical condition. Very few painters in the Western tradition painted illness; the importance of Velazquez' work lies in the exposure of physical and mental disability - bringing them into public awareness. De Morra's dignity lies in his struggle against the humiliating situation of his body, as well as against the culture that looks down upon the disabled, displaying disdain, scorn and condescension, while linking disease with humiliation, both limiting and hindering one's autonomy (Honneth, 1992). He is protesting against a world order, a rigid and cruel monarchic regime that exclusively determines its subjects' fate. He shows his frustration at how disability damages his physical independence and at the social conventions that interpret his physical limitations to a degree that extremely restricts his self-actualization depriving him of his sense of self-worth. Honneth claimed that while the dwarves were deprived of the autonomy of their self-actualization, the meaning and consequences of being short- statured was determined by the ruling authorities and not by the dwarves themselves (Honneth, 1992). Honneth went on to treat de Morra's raging outcry against the unspeakable injustice preventing and rejecting possible activities by normative constraints (Honneth, 1992). 
This protest was the source of a moral and political reform as it served as motivation and catalyst against the existing order. Amazingly, it took place during the period which eliminated human rights (Muller, 1976), since the dwarves were permitted to behave and act in an undignified manner, enjoying freedom of speech - regarded by their audience as irrelevant babbling and thus unpunishable. According to Honneth, this behavior was allowed by the royals, perceiving it as a child's tantrum of one who lacks social skills (Honneth, 1992).

The importance of this painting is that whatever is defined by the observer as a "curiosity," challenges not only the very definition but also the validity and meaning of existence within that definition. De Morra confronts those above him on the political level, and demands to be treated equally.

Despite the humiliation that hindered the dwarves' achievements and personal development and consequently their autonomy, de Morra earns dignity and respect through the high intelligence conveyed by his face, reflecting assertiveness, concentration, determination, dissatisfaction and defiance. Despite being exploited as a source of entertainment and amusement, he expresses, as one of God's creatures, self-respect, respect for his kind and the social stratum he represents, even though his soul is being held captive in his "dwarf prison." As Kant put it, a person is the final goal and being human has value in itself, independent of anything else and regardless of whether they are enjoying life or improving the lives of others (Kant, 1964).

Displaying the dwarf's dignity is achieved not via a positive representation of worthy activity or the presentation of a lofty ideal according to which one can be held in high esteem, but via a negative approach, as it were, protesting against humiliation by those discriminating against De Morra and preventing him from participating in society.
$\Lambda^{1}$ $\mathrm{t}$ first glance, two visual basics seem to be missing in The Surrender of Breda (1634) also by Diego Velázquez: the commander of the victorious army on horseback and the commander of the vanquished army on his knees.
How military commanders treat their defeated enemies in war is an indi- cation of their character. The typical war scene would show the conqueror demonstrating his power mounted on a horse while the surrendering leader would kneel before him as a sign of his submission, humiliated and scorned. Velázquez' painting caused a revolution in the genre of war paintings, by emphasizing that a great commander or leader is actually tested by the ele- gance and generosity he displays toward his fallen enemy rather than by his cruelty.
This was the case in this work, also known as The Lances, in which he commemorates the conquest of Breda in the 80-year war between Spain and Holland, fighting for its independence. The subject of the painting is the mili- tary triumph of the Spanish army. However, the artist chose to eliminate any bloody or violent aspect from his canvas. Instead, he portrays the surrender of the Dutch, whom he places on the left of the painting as young, few in number and in complete disarray. In contrast, the Spanish on the right appear to be a 
large, organised and cohesive group. The spears in the background create the impression that the number of well-trained Spanish soldiers was indeed much greater.

The painting focuses on the key to the city. Marquis General Imbrogio Spinola, the head of the Spanish forces is receiving it from Justinius van Nassau, three days after the surrender on the 8th of June 1625, and with great noblesse places his arm on his enemy's shoulder showing understanding, despite his superiority, probably to prevent the Dutch commander from kneeling as was customary in such circumstances. Nassau, who was presumably about to do what was expected was surprised by this gesture of human compassion and generosity of spirit when he felt the unexpected tap on his shoulder from his enemy. Wagner-Pacific explained that this very noble gesture was indeed different from the conventional scenes as it offers a very cultured image of the Spanish conqueror maintaining the dignity of the conquered rather than exhibiting revenge (Wagner-Pacific, 2005).

The battle is behind them, with just wisps of smoke lingering in the background.

The heart of the picture is this human encounter with the two commanders in the forefront emphasized by the artist. The surrender scene is radically different from conventional ones, emphasizing the touching human aspect, the empathy, generosity, kindness and humaneness, a scene in which the commander who has the upper hand refuses to humiliate his opponent on the battlefield and treats him as an equal, almost as a brother-in arms.

The two-fold expression of extraordinary dignity is demonstrated, as mentioned, firstly in the true definition of a great leader or commander's personality and the generosity of spirit he displays (Berzal, 2013); secondly, it is that dignity extended to Justinius van Nassau the human being rather than the military leader who becomes the beneficiary of same. This work's theme, then, is a gesture of consideration devoid of any condescension.

$\mathrm{V}$

incent van Gogh (1853-1890), who was never a prosaic realist and who saw painting as a visual ecstasy, illustrates the aura of dignity in a scene that contains a feeling of crowding, meagerness, isolation, sadness and poverty.

At first glance, the observer encounters shadows along the facial features of those seated around a table; blotches of gray shadow accompanying the coffee cups and potatoes in a dish. A family of Dutch farmers - five figures whose faces - the color of dusty unpeeled potatoes - are wrinkled, ugly, brutish and distorted - is partaking of a meal in a dark, gloomy and cramped space, in his 1885 painting The Potato Eaters.

During this period, Van Gogh documented the brotherhood and the identification he felt towards these poverty-stricken laborers whose distress and adversities he was only too aware of. He painted several farm-hands, coal-miners, weavers and villagers all struggling with the burdens of life because of the solidarity and affinity he felt for the poor and his profound revulsion for the mechanization and industrialization processes that were turning men into 
machines. Van Gogh refused to embellish or prettify these figures and had no qualms about presenting them with no refinement, preferring to depict them as they were in reality. He even wrote that a stable should smell of horse excrement, while fields should smell of ripe corn and potatoes and those who work the land should not smell of perfume (Van Gogh, 2000). The walls of the room in which the malnourished and impoverished family is seated are bare and in drab colors. There is a great physical similarity between the peasants' facial features and their expressions as they share their meal, late in the evening, consisting solely of potatoes - the most basic dish, but also the factor that provides them with family cohesion, if not satiation.

The oil lantern hanging down from the low ceiling over the center of the table illuminates the darkened room with its yellow flame and is the only source of light that creates any warmth in the cave-like threatening space. It is a soft golden light - almost spiritual yet it unveils the depressing confined conditions of this hovel baring the gloom that encompasses the room and the faces of the figures on which the hardships and the burdened life are etched. At the same time, it reveals the internal resilience of this united family as well as the overcoming of the individual's solitude and the harshness of nature.

These people tired, anxious and concerned are focused only on their inner world. Van Gogh who knew the people in the community of which he had been a priest, intentionally chose unspoiled, crude, homely figures as the most natural for this topic distorting their faces to the extreme. Their faces are flattened, the foreheads low, their lips thick, their cheekbones prominent, their eyebrows are low and their large and wide open eyes - staring. Most of them seem devoid of intelligence or sensitivity, almost like grotesque caricatures, a prototype of primitive man. However, van Gogh had no intention of mocking them, but rather tried to show the farm-hands in their purest form, as representing the ancient traditional values of harmonious country life in their as yet uncorrupted natural environment.

Despite their outward appearance, warmth, brotherhood and caring for each other are nevertheless conveyed. They share what little they have with one another. After the day's work, these peasants look exhausted, as if their bodies had given up on the fight for life. Their poorly proportioned features highlight van Gogh's perception of beauty, which had developed seeing the people around him. For him they embodied the real truth, with an inner beauty and the simplicity, companionship and love of their fellow men.

This gloomy painting employs a humanitarian approach and simultaneously presents people's misery as well as a reflection of van Gogh's profoundly religious sentiment. In the seriousness of the characters and their limited movements he saw holy people, much alike to those seated at the Last Supper (Wessels, 1913). The table was their altar and the food their sacrament. By rendering this commonplace event meaningful, van Gogh depicted a close community whose meal was an occasion for them to share the fruits of their labor, revealing humanity, dignity, and moral beauty (Schapiro, 1983). Sometimes at family meals, moments of silence might be awkward or uncomfortable 
for those present, but van Gogh portrays a different kind of quiet, one that is intimate, warm and unifying, dispelling any kind of discomfort. The sense of unity that envelops the family is also achieved through highlighting peasant's earthy, emaciated and gnarled hands as if created from that same earth they had been digging. However, those skeletal and callused, oversized hands indicate the mutual love shared by the members of this family being filled with closeness, affection and concern for each other, uniting them all.

In a letter to his brother Theo, van Gogh expressed his wish that the observer know that these potato eaters who dug with their hands into the dish during the meal, used the very same hands to dig up the soil when gathering the potatoes, hence earning their meal honestly (Van Gogh, 2000).

Inner, moral beauty and the strong bond expressed in the common meal and the passing of the food to each other coupled with a sense of selflessness gives this work a calming ambience, which enhances the atmosphere of dignity. The same hands expressing poverty share in creating the reciprocal concern and devotion that lead to it. Despite the absence of verbal communication between those present at the table, or even of any exchange of mutual glances, communication is achieved by their hand gestures.

This painting reflects van Gogh's main goal in portraying the human spirit, injecting life into the wild nature and the culturally untamed countenances of those who till the soil on which their livelihood depends.

Van Gogh commented that he preferred painting the human soul and mainly that of a beggar or a homeless person explaining further that he found more joy in painting the eyes of people than in painting cathedrals (Van Gogh, 2000).

Auguste Rodin (1840-1917) worked for seven years on his statue of Honoré de Balzac (1891-1898) exhibiting it only after making some 40 versions of the torso and different parts of the body in wax, clay, bronze, plaster and marble, decades after Balzac's death. According to Cladel (1936), Rodin said that nothing he had ever done had given him such great satisfaction since nothing else had demanded such tremendous effort. He claimed that none of his other works so profoundly summarized what he believed to be the secret commandment of his art (Cladel, 1936). Honoré de Balzac (1799-1850) was one of the most prolific and industrious novelists in the history of French literature, and one of the great creators of realism. His works systematically portrayed the various social strata of French society of his era from a somewhat cynical perspective. He mainly criticized the crumbling of morality and the dominance of wealth. His great life's work La Comédie Humaine, which was greatly admired by Rodin, contained over 90 works and is considered to be one of the great legacies of world literature. Balzac admitted that inside himself many "Balzacs" resided, if all the participants in that monumental work were taken into account.

The Paris Writers' Association commissioned a sculpture to commemorate this great author, who died in 1850. Auguste Rodin, who had not known the object of his future work in person, studied his personality through photographs, through everything written about him by scholars and by reading his 
books, all in order to obtain a sense of who Balzac really was. In order to create the statue, Rodin felt that he had to highlight not so much the man's physical appearance, but rather his spirit, his creative vitality, his character and his greatness as a writer, a highly perceptive thinker, a visionary, a prophet. Likewise he felt he was to portray the man's efforts, his works, his wearying battles and his courage.

Rodin faced one serious dilemma: how would he sculpt this multifaceted figure? The challenge was especially daunting, given this esteemed author's outward appearance being far from impressive, thus preventing the sculptor from creating a realistic sculpture that might end up as the object of mockery and scorn. The sculptor sought to protect the dignity of Honore de Balzac, the author: a gesture of respect like none other. He had to portray the unusual shape of his short, stocky figure, with its protruding belly, thick neck and short arms and legs; not to mention his complex character and unique personality, but mainly, he had to take into consideration his extensive and brilliant body of literary work, showing it at the birth of ideas. Balzac used to write at night, wearing a robe; he ate and drank continuously while pacing his room, his arms crossed over his exposed belly. Thus, Rodin had to create a timeless representation of the spirituality and intensity of the writer on the one hand that would still resemble him, on the other.

Balzac was known to be a hedonist and a highly social animal, which constituted a biographical detail the sculptor wished to highlight. He emphasized the shape of the body through the dimensions of the statue and the upright position that suited the figure of the author. Balzac was known for his elegant style of dress and in public, always wore a blue cloak with gold buttons, a sight etched in the public memory, an important detail in the portrayal of his personality. Rodin created a sculpture of a large man whose body consisted of one solid piece of cloak devoid of any adornment. This allowed Rodin to conceal the shape of the body and the arms, highlighting the empty sleeves hanging down from it. The heavy upturned head which is merging with the shoulders gives him stature, while his eyes deep-set are looking out into the distance while at the same time sending a penetrating look of profound irony mixed with sadness at the crowds observing him. His pulled-back hair is somewhat wild. This figure, concealing the anatomical details, moves far away from naturalism while approaching the abstract.

Balzac's arms are crossed beneath the cloak; his posture is erect and full of self-worth, his right foot slightly in front of his left - all these features creating the image of a giant, an extraordinary genius. Rodin focused on the awkward stockiness and the drama, but bridged the imaginary with authenticity by endowing Balzac with a very singular character. The texture of the figure has a rough finish, as Rodin chose not to polish it: a technique meant to indicate the author's intellectual power.

The sculpture appears to be solid and immoveable, but is not perceived as motionless. In addition to the forward movement of the foot, Balzac appears to be moving in several directions simultaneously. The main movement is 
that leading towards the head, backwards, as he looks up. Rodin himself declared that his Balzac represented a deliberate step towards outdoor sculpture (Rodin, 1921). Like others, this work aroused stormy debate with very wrathful reactions such as "a sack of coal," "a penguin," "a shapeless dummy," "a walrus," “a ghost" and even "an ambitious Napoleon" (http:/ / www.nytimes.com/1998/08/15/style/saga-of-a-statuethe-struggles-ofrodins-balzac.html).

The Balzac statue preceded its time and paved the way for new forms of expression in sculpture, primarily, by its ignoring the humble imitation of reality, which had been the convention until then, as well as by the bold and daring abstraction of the figure: a monumental and symbolic statue of one of the great figures of the era - both physically and spiritually. The Balzac, whose head was larger than in Rodin's earlier statues, is shown to be powerful, focused, a visionary who sees into and beyond things; introspective and yet looking ahead; reaching higher illuminated spheres as well as the edge of the abyss. He is impressive in his wisdom but is also gloomy and tragic.

The many models Rodin made for this statue is indicative of how exhaustively he searched for the right expressive and dramatic way that would portray the essence of Balzac's personality. While he was working on it, his concept of describing the figure changed from a rather naturalist figure of a young man to a more romantic aging visionary, a figure symbolizing the writer rather than representing him. Rodin made outlines of some 20 heads, trying to capture the great writer's reflections and observations of reality and thus, he focused on designing the head as a symbol of the soul or of wisdom. He claimed that it was the emotion, the soul, the man's intimate inner life that he was trying to reach, but nothing was simple with Balzac (Butler, 1993).

In the final result, Rodin succeeded in presenting a highly dramatic and expressive form: a life-size bronze statue containing realism in terms of the art of typical portraiture, as well as the spirit and the greatness of soul. The sculptor managed to grasp Balzac's creative power, his energy and literary intensity solely with the head and the enormous cloak.

The arms in this statue are notably absent. This absence plays a role that goes beyond the technical solution of concealing the author's belly. They were eliminated because, their dynamism, might have detracted from the body's impressive presence topped by the massive head, and from the dominant contemplative essence emanating from his face. Rilke summed up the Balzac by relating to the perfection in Rodin's armless statues, claiming that nothing essential was missing (Rilke, 1945).

Auguste Rodin was immensely proud of this statue, describing it as the focus and axis of his esthetics; the pinnacle of his life's achievements; the essence of his artistry. He further claimed that from the moment he conceived of the idea of it, he became a new man (Normand-Romain, 2014).

The dignity bursting forth from this statue derives from the sculptor's tribute to Balzac, translated into a figure of dignified presence, vision, power and high self-esteem - all radiating from the artistic and content design and from 
the great height Rodin bestowed on him. All observers would look upward towards him.

In his critique, journalist Gaston Leroux wrote saying that this legless and armless Balzac lacks everything except eyebrows, two holes, two eyes and one lip. Thanks to the eyes and the lip, Rodin should be forgiven for the missing arms and for everything else that was not there. Leroux went on to say that he could imagine Rodin sculpting the whole of Balzac and then starting to eliminate everything over months: muscles, arms, legs, and anything else that was not useful as it did not express what this man saw with his eyes and felt with his one lip (Leroux, 1898).

Moses - a complex and legendary biblical figure, full of internal and external contrasts and contradictions, is revealed in this impressive image radiating honor and dignity in the rendition of Moses by Michelangelo (1475-1564), signifying thought and wisdom, with his soul seemingly embedded into the marble.

As the forefather of Judaism and Jewish nationhood, Moses became a key symbol in history and left an everlasting legacy for future generations. The tragic aspect of his life was that despite all that he accomplished, and all his wonderful achievements, he was unable to fully realize his vision or his final destiny. He who had redeemed the Israelites from slavery and was denied entry into the Promised Land due to his weaknesses and sins (beating on the rock and shattering the tablets) was restored his status of a mere mortal.

According to the Talmudic sources, his uniqueness began when he exhibited gentleness and compassion as a shepherd in his youth, understanding the suffering of a thirsty lamb, taking pity on a lost goat which was later reflected in the tenderness towards his people.

Moses' biography included his being the first Hebrew diplomat, sent to Pharaoh to negotiate with him and his entourage; as the educator and legislator of his people, bringing them the laws and commandments written by God's hand on the first tablets; as the fashioner of moral and social values and of the Jewish faith, creating the awareness of tribal unity; as the savior of the Israelites and the leader of a stubborn people for 40 years in the desert following the exodus from Egypt. He was also a spiritual and military leader involved in the battles against the Amalek, the Sihon the Emorite and Og, King of Bashan, and in the battle for revenge against the Midianites and the defender of Israel against the wrath of God. He was the only mortal who stayed 40 days and 40 nights on Mt. Sinai deprived of food and water; a man of principles from which he never strayed. He was the master of prophets - a man of absolute truth, justice and morality, uncompromising and unbiased. Moses, the man, this giant of a figure, was the most humble and modest of any who walked the earth.

The Moses was part of the tomb of Pope Julius II, who, in 1505, charged Michelangelo with the task of building a tombstone that would be more grandiose than any similar work before it (Barasch, 1961). Julius' tomb was meant to demonstrate the triumph of the soul over the material world (Hibbard, 1979).

Michelangelo was inspired by Neo-platonism, according to which man is the link between God and the world, as was, indeed, the role that Moses played 
(Goldstein, 1992): mediating between the divine and the mortal. According to Barolsky (1997, p. 158), the profound spirituality of Moses is evident in the massive proportions and power of the statue as well as from the terribilità that the artist was able to bring to his face. Howard Hibbard (1928-1984) explains the term as "awe, threatening power or as sublime" (Hibbard, 1979, p. 85). This is where the intense aura of dignity radiates from in the Moses.

His pondering, distant look seemingly focused on the future, peers upwards and beyond - to the higher spheres (Hedges, 2011). Alongside the threatening intensity, it possesses restrained emotional and spiritual energy, the quashed anger and disappointment at the thought of his people singing and dancing around the Golden Calf; the deeply penetrating gaze causes the observer from any angle to feel awe and reluctance to approach him on the one hand, but at the same time to feel the pity and compassion radiating from him on the other. According to Vasari (2003, p. 132), Michelangelo's biographer Ascanio Condivi (1525-1574) claimed that the face of Moses evoked both love and fear. According to Freud, Moses resembled a human volcano about to erupt in righteous anger. Like other Michelangelo's figures, it creates an ambience of awe, the result of artist's belief in the constant confrontation between the body and the soul (Freud, 1955).

Michelangelo portrays Moses in midlife and in his prime, a large figure that is physically and mentally robust, 2.35 meters in height; his physical strength expressed in his limbs, especially his muscular arms, and alongside it, humility and modesty. His hands are close to his body, indicating the lack of externalization of his superior status or any display of condescension.

Michelangelo's ability to express the intensity of the radiating inner strength makes the observer feel the trembling that overcame Moses when he felt such loathing for his people.

Moses has two distinct focal points: the upper half of his body - the divine element, and the lower half - the practical element. In his article The Book of Moses in the Book of David, Yair Zakowitch reveals a new facet of Moses that does not come from the Torah, but from other biblical writings: "And some explained that the two-faced figure is: his lower half - human; his upper half Divine" (Zakovitch, 2010).

The sensitive hands of Moses gently fondle his beard. This beard is extraordinarily long, evoking an association with flowing-streaming water, while his wavy hair creates an image of flickering flames. This contrast of fire and water symbolizes the two focal points of Moses' experience - the Burning Bush and the Red Sea.

The mass of beard curling down from lip to abdomen gives this Moses a wondrous, legendary appearance mingled with softness and human kindness. Perhaps with this beard the artist sought to express the miracles Moses performed, thereby highlighting the mythical quality of this unique character.

Although he is seated, the manner in which he holds his torso and head indicates the dignity surrounding him as befits the judge of his people. His seated pose might also testify as to his humility, since his full glory might have 
been more prominent if the statue had portrayed him in an upright pose. His determined expression suggests an "absolute" adherence to his purpose, from which he would not stray left or right - the uncompromising man of justice.

In this statue, Moses quashes his mounting anger, blocking its eruption and remains seated, restraining his energy, vitality and even nobility and confidence. Sigmund Freud believed that when seated he could refrain from throwing down the tablets he was protecting. Freud felt that the statue did not express a particular moment nor a historical figure, but rather a type of character embodying inner strength taming a stubborn and rebellious world. The secret element to the dignity enveloping Michelangelo's Moses lies in the contrast between the inner passion and the outward calm emanating from his presence (Freud, 1955). As his wrath rose, Moses wanted to act, to leap up, take revenge and shatter the tablets, but he overcame this temptation and henceforth remained seated, his anger frozen and his pain mixed with scorn. Giving in to his urges would have led to neglecting or destroying the tablets; therefore, he subdued his spirit preventing himself from acting in an extreme fashion. Moses attained the highest human mental achievement: conquering his inner passion; for his life-long goal had been: self-restraint and overcoming urges. Thus, Moses remained seated and following this approach, Michelangelo placed him as the guard to the tomb (Freud, 1955). This position highlights Moses' patient and tolerant attitude towards the obstinate Israelites.

The figure of Moses is full of vitality, power, alertness and calm, thought and action: an exemplary figure of the material and the spiritual (Simmons, 2006). Michelangelo chose to portray in marble the biography and ensemble of qualities of the Master of Prophets, the unforgettably unique figure: the mortal who came the closest ever to God, who stood on Mount Nebo at the gateway to the Promised Land but was forbidden from entering.

According to Simmons (2006), art historian Erwin Panofsky (1892-1968) claimed that Moses attained spiritual immortality even in his life on earth because of his perfect synthesis of action and vision. Even though he is better remembered as the legislator and ruler than as a man of vision, he possessed inner sight and was sculpted by Michelangelo as a leader and prophet who through inspiration saw what the Neo-Platonists called the 'splendor of divine light' the very same dignity that is the theme of this article.

\section{CONCLUSION}

The word Dignity comes from the Latin decus meaning: ornament, distinction, honor and glory, i.e. excellence or incomparability of value, which in a human being induce or ought to induce respect. Simply put, human dignity means an inherent fundamental quality or moral stature entitling human beings to said respect which they can never be deprived of.

In scenes such as: a military surrender; a preference of an inner rather than exterior portrait; a challenging gaze protesting against humiliation; familial 
cohesion; supreme self- confidence; ambience of divine awe - all depicted in this article - the different visual facets of human dignity are portrayed.

This artistic mosaic is composed of figures whose life-styles, roles in society, looks, traits and social status are so dissimilar that one would be baffled by their inclusion in one article were it not for that inherent quality they shared: radiating that deep value of inner beauty - that which is invisible and yet so obvious.

\section{REFERENCES}

[1] Barasch, M. (1961). Michelangelo. Jerusalem: Mossad Bialik.

[2] Barolsky, P. (1997). Michelangelo's Nose: a Myth and its Maker. University Park: The Pennsylvania State University Press.

[3] Berzal, J. (2013). Velasquez, The Surrender of Breda. Khan Academy.

[4] Brinkley, C. (2012). Bearing the Cross: Devotions on Albrecht Durer's Small Passion. Saint Louis: Concordia Publishing House.

[5] Brion, M. (1960). Durer, His Life and Work. London: Thames and Hudson.

[6] Brown, J., \& Garrido, C. (1998). Velazquez: The Technique of Genius. New Haven: Yale University Press.

[7] Butler, R. (1993). Rodin, The Shape of a Genius. New Haven: Yale University Press.

[8] Cladel, J. (1936). Rodin, The Man and His Art, Paris: Grasset.

[9] Conway, W. (1958). The Writings of Albrecht Durer. New York: Philosophical Library.

[10] Dobrzynski, J. (2008). Staring Durer in the Face. The Wall Street Journal, 15/3/ 2008.

[11] Edgar, E. (2003). Velasquez and the Representation of Dignity. Medicine, Health Care and Philosophy, 6, 111-121.

[12] Freud, S. (1955). The Moses of Michelangelo in The Standard Edition of the Complete Psychological Works of Sigmund Freud. London: The Hogarth Press.

[13] Goldstein, B. (1992). Reinscribing Moses: Heine, Kafka, Freud, and Schoenberg in a European Wilderness. Cambridge: Harvard University Press.

[14] Hedges, J. (2011). Michelangelo's Moses of the Julius Tomb: The Definitive Michelangelo's Sculpture. Medievalist.net.

[15] Hibbard, H. (1979). Michelangelo. New York: Harper \& Row.

[16] Honneth, A. (1992). Integrity and Disrespect: Principles of a Conception of Morality Based on the Theory of Recognition. Political Theory, 20 (2), 192.

[17] Janson, W. (2001). History of Art. Englewood Cliffs N.J: Prentice Hall, Inc.

[18] Jones, J. (2002). Velasquez's Dwarf Sitting on the Floor. The Guardian: Saturday Review, May $13^{\text {th }}, 6$.

[19] Kant, I. (1964). Groundwork of the Metaphysics of Morals. New York: Harper and Row Publishers.

[20] Leroux, G. (1898). A Paris: LeVernissage. Le Matin, May 1.

[21] Muller, J. (1976). Velazquez, London: Thames and Hudson.

[22] Nordenfelt, L. (2009). Dignity in Care for Older People, West Sussex: Wiley-Blackwell.

[23] Normand-Romain, A. (2014). Auguste Rodin, New York: Abbeville Press Publishers.

[24] O'hara, A. (1999). Human Dignity, Abingdon-on-Thames: Routledge

[25] Rilke, M. (1945). Auguste Rodin. New York: The Fine Editions Press.

[26] Rodin, A. (1921). Les Cathedrales de France. Paris: Armand Colin.

[27] Schapiro, M. (1983). Vincent Van Gogh, New York: Harry N. Abrams.

[28] Simmons, L. (2006). Freud's Italian Journey. Amsterdam: Rodopi B.V.

[29] Van Gogh, V. (2000). The Complete Letters of Vincent Van Gogh, New York: Bullfinch Press.

[30] Vasari, G. (2003). Life of Michelangelo. New York: Alba House.

[31] Wagner-Pacific, R. (2005). The Art of Surrender: Decomposing of Sovereignty at Conflict's End. Chicago: University of Chicago Press.

[32] Wessels, A. (2013). Van Gogh and the Art of Living, Eugene, Oregon: Wipe and Stock.

[33] Zakovitch, Y. (2010). The Book of Moses within the Book of David. Ramat Gan: Bar Ilan University. 